\title{
Um Equilíbrio Delicado: A Dinâmica das Coligações do PT em Eleições Municipais $(2000 \text { e } 2004)^{*}$
}

\author{
Luis Felipe Miguel \\ Carlos Machado
}

$\mathrm{D}$ esde sua fundação, em 1980, o Partido dos Trabalhadores - PT tem sido alvo do trabalho de cientistas sociais - e não só do Brasil. Entre livros, artigos, teses e dissertações, a bibliografia sobre o PT pode ser contada às centenas ${ }^{1}$. São muitos os motivos deste interesse. Ainda que bebendo da experiência anterior das lutas operárias no Brasil, das organizações da esquerda marxista e das comunidades da Igreja católica, o PT representou uma experiência nova de organização política, diferenciada tanto pela origem social de sua liderança quanto pela relação que buscava manter com os movimentos populares que consistiam sua base. Conforme Haquira Osakabe (1987) disse de Luiz Inácio Lula da Silva, o partido trazia à arena política uma "palavra imperfeita". Não apenas porque nela introduzia, de forma inédita no Brasil, a prosódia e a sintaxe próprias das classes populares, mas imperfeita sobretudo porque não se prendia às fórmulas acabadas, aos modelos prontos das esquerdas tradicionais e, muito menos, das elites estabelecidas. $\mathrm{O}$ discurso se alimentava da experiência vivida dos trabalhadores e dos embates cotidianos dos movimentos sociais. Ainda, é claro, que esta "palavra" não pudesse ser atribuída de forma homogênea a todo o partido, devendo o sucesso de sua empreitada política à capacidade de

\footnotetext{
*Os autores agradecem a Regina Dalcastagnè pelas críticas e sugestões a uma versão preliminar do artigo, bem como aos pareceristas anônimos de DADOS.

**Ver lista de siglas dos partidos políticos com os respectivos significados ao final do artigo.

DADOS - Revista de Ciências Sociais, Rio de Janeiro, Vol. 50, n4 4, 2007, pp. 757 a 793.
} 
absorver uma enorme diversidade de correntes políticas, desde o seu início até hoje (Oliveira, 2003).

No entanto, a trajetória do PT e de Lula é marcada pelo contínuo "aperfeiçoamento" de sua palavra, em especial após as eleições de 1989 (Miguel, 2006). Ao deixar a posição secundária que até então ocupava no sistema político brasileiro, como voz de grupos puristas e radicais, para se tornar a referência central da esquerda e uma alternativa efetiva de poder, o PT mudou seu discurso, suas práticas e seu programa. $\mathrm{O}$ sucesso eleitoral impôs sua pedagogia aos petistas, que abandonaram o basismo, o antieleitoralismo, o principismo, o sectarismo mesmo dos primeiros tempos. Em seu lugar, vieram o pragmatismo, a moderação, a acomodação com as práticas políticas vigentes. De uma organização que freqüentemente participava das eleições com o intuito de marcar posição e fazer proselitismo, nasceu outra, que concorria para vencer, com todas as implicações desta afirmação. Sob este ponto de vista, a trajetória do PT é um caso exemplar dos constrangimentos que o campo político inflige ao discurso e à prática política dos dominados (Bourdieu, 1979).

Dois elementos, em especial, ilustram as transformações do petismo. $\mathrm{O}$ primeiro é a construção da imagem pública de Lula, sobretudo nas eleições. Do "trabalhador igual a você" nos anos 1980, em que a especificidade e o valor da condição operária eram afirmados com radicalidade, chega-se em 2002 ao negociador, ao conciliador e ao líder político vitorioso, que claramente não é "igual a você" (Rubim, 2003; Miguel, 2006). O segundo é a política de alianças. Em 1989, o PT recusa o apoio, no segundo turno da eleição presidencial, de um conservador respeitável como Ulysses Guimarães. Em 2002, coligado com o direitista PL, coleciona a adesão de oligarcas como José Sarney ou Antônio Carlos Magalhães.

Este artigo analisa a evolução da política de coligações do PT nas eleições municipais brasileiras. Ela é intuitivamente descrita como uma progressão rumo ao pragmatismo. No entanto, é necessário observar que o purismo petista inicial correspondia, também, a uma resposta às oportunidades abertas pelo campo político no momento. Pagando o preço de derrotas eleitorais nas primeiras disputas, o PT pôde constituir uma identidade e, simultaneamente, constituir-se como marca político-partidária, muito mais do que qualquer outra legenda brasileira. $\mathrm{Na}$ hora de se abrir para a barganha, em busca de vitórias, estava em posi- 
ção vantajosa. Assim, ainda que de maneira não plenamente consciente, o partido estabeleceu uma estratégia de longo prazo, acumulando um capital de credibilidade que seria resgatado no momento adequado.

\section{COLIGAÇÕES}

A ampla utilização de coligações partidárias nas disputas eleitorais é uma das características marcantes da vida política brasileira - algo presente no experimento democrático de 1945-1964 e que foi retomado após a redemocratização de 1985 . Uma perspectiva positiva vê nas coligações "mecanismos democráticos de relacionamento" que ampliam a tolerância entre interesses divergentes (Favetti, 2004:1). Outra, mais crítica e possivelmente mais difundida, julga que elas tornam ainda mais confuso, para o eleitor, um sistema partidário que já é gelatinoso, e que, aplicadas às eleições legislativas, contradizem a rationale da representação proporcional (por exemplo, Tavares, 1994).

No caso das eleições proporcionais, um poderoso estímulo às coligações é que elas facilitam a ultrapassagem do quociente eleitoral, que funciona como cláusula de barreira. Para os cargos majoritários, as coligações são, muitas vezes, um subproduto das alianças firmadas com vistas às eleições proporcionais; em relação ao Poder Executivo, há a esperança de que, em caso de vitória, os partidos apoiadores sejam contemplados com cargos na administração pública. Os candidatos apoiados ganham com a redução do número de adversários, com o presumido suporte dos líderes e candidatos ao Legislativo dos outros partidos - apenas "presumido" porque, nas condições de fraca identificação partidária existentes no Brasil, é freqüente que militantes e mesmo dirigentes apóiem candidatos que não são os de seu partido - e com a ampliação do tempo de que dispõem no Horário Gratuito de Propaganda Eleitoral - HGPE na televisão e no rádio. Importante nas disputas nacionais, estaduais e nos municípios de médio e grande porte (que possuem emissoras em condições de transmiti-lo), o HGPE é um "grande mecanismo de valorização das hierarquias partidárias" (Miguel, 2004a:239), na medida em que, para a distribuição do tempo, contam apenas as decisões formais, não o apoio real dentro de cada partido, e um dos principais elementos da barganha na construção das coligações.

De maneira esquemática, é possível identificar duas abordagens às coligações partidárias. A perspectiva ideológica julga que a coligação é um 
instrumento que permite que partidos que se encontram próximos uns dos outros no espectro esquerda-direita ampliem suas chances de vitória contra adversários situados em posição oposta ${ }^{2}$. Já a perspectiva pragmática acredita que os competidores com chances reais na disputa buscam o maior número possível de apoios, não importa de onde venham, a fim de garantir a máxima vantagem sobre seus adversários. Nas eleições presidenciais, o PT, que em 1989, 1994 e 1998 se coligou com PC do B, PSB, PPS, PSTU, PV, PDT e PCB, assumindo a primeira perspectiva, teria passado à segunda em 2002 e 2006, ao se aliar aos direitistas PL e PRB.

Mas estas abordagens são insuficientes. Em primeiro lugar, porque ideologia e pragmatismo não explicam a variedade de comportamentos dos partidos nas disputas eleitorais. E também porque ideologia e pragmatismo não são características naturais de um ou outro ator político, nem opções sempre à disposição, a serem escolhidas aleatoriamente. O comportamento diante das possibilidades de coligação é efeito das trajetórias dos partidos no campo político; ideologia e pragmatismo não são mutuamente excludentes e, pelo contrário, por vezes se confundem.

A forma pela qual visões de mundo são ofertadas na disputa eleitoral é crucial para compreender a interação entre sociedade e partidos. Como observou Bourdieu, na prática o processo representativo é invertido. Não são os representantes que expressam as vontades da base, mas os eleitores, reduzidos à posição de consumidores, que devem escolher entre as ofertas a eles apresentadas (1989:164). Assim, os partidos são os responsáveis por indicar quais os aspectos mais relevantes à discussão política. Há que lembrar, ainda, que, no caso brasileiro, os partidos políticos foram constituídos de cima para baixo (Mainwaring, 2001), o que reforça o caráter reativo da opção eleitoral ${ }^{3}$.

A atitude de um partido não depende apenas dele mesmo, ela se constrói a partir de experiências sociais e políticas de seus dirigentes, combinadas com as regras que limitam a atividade política. Estas normas beneficiam alguns comportamentos e prejudicam outros. $\mathrm{O}$ arranjo institucional brasileiro tem privilegiado a constituição de coligações, independentemente da orientação ideológica dos participantes. A ausência de lealdades fortes, que vinculam parcelas do eleitorado a determinadas legendas, faz com que o ônus simbólico de coligações ideologicamente estranhas seja, para quase todos os partidos, reduzido. 
No que diz respeito a possíveis explicações de comportamentos partidários, Soares (1964) é pioneiro ao resumir os motivos por trás das coligações em duas teorias. A decisão de realizar coligação dever-se-ia a um cálculo racional no intuito de economizar recursos de mobilização. Sendo assim, haveria uma "economia de esforços" pelos partidos, as chances de alcançar a votação necessária para eleição aumentariam e os custos seriam repartidos entre os participantes da coligação. Contudo, a busca pela maximização de benefícios não ignora os custos que poderiam advir de uma aliança com grupos ideologicamente díspares. Desta forma, haveria uma "resistência ideológica" ao determinar quais parceiros não trariam desvantagens eleitorais.

Vários estudos tomam por base esta classificação, seja para corroborá-la ou refutá-la ${ }^{4}$. Oliveira (1973) afirma que as inconsistências ideológicas não são relevantes, tese contestada por Soares (2001). Souza (1976) observa que o período 1945-64 apresenta uma reconfiguração ideológica que, apesar de interrompida pelo golpe militar, caminhava para uma melhor estruturação do sistema partidário, na qual a nacionalização de projetos partidários significava o declínio das forças locais e o aumento da racionalização dos perfis partidários para uma melhor compreensão sobre as opções políticas por parte dos eleitores. No período pós-ditadura, esta nacionalização mantém-se, guiada por uma força centrípeta, mesmo que parceiros no nível federal possam ser adversários estaduais (Krause, 2005; Ribeiro, 2005).

Contrário à perspectiva de nacionalização dos partidos, Lima Júnior (1983) afirma que o principal motivo da constituição de alianças é aumentar o apoio local a um candidato e, com isso, impossibilitar alianças com o principal adversário. A partir desta perspectiva, a necessidade de apoio é fundamental para o ganho eleitoral ou político. A princípio, os maiores beneficiários de uma coligação seriam os partidos menores, pois teriam acesso à representação no sistema proporcional. Porém, uma série de estudos aponta para a importância de apoio político nas eleições majoritárias. Partidos pequenos coligam-se aos grandes em eleições majoritárias com a intenção de receber cargos e benefícios (Lavareda, 1991; Soares, 2001), enquanto partidos grandes buscam apoio dos menores quando a disputa está polarizada e não existe certeza quanto ao resultado da eleição (Fleischer, 1984). Para os grandes partidos, entre os benefícios de se coligar estaria o aumento do tempo no HGPE, uma das principais formas de interação dos candidatos com 
os eleitores (Schmitt, 2005; Schmitt, Carneiro e Kuschnir, 1999; Nicolau, 1996).

Se na maior parte dos estudos sobre coligações as investigações são calcadas na observação sem reflexão sobre as conseqüências destas para o processo político, alguns autores nadam contra a corrente. É interessante questionar se o papel dos partidos políticos restringe-se apenas a vencer eleições ou está conjugado com a representação de interesses presentes na sociedade. No segundo caso, as coligações tenderiam a obscurecer as opções políticas e trariam irracionalidade para o processo (Tavares, 1998$)^{5}$, provocando, desta forma, distorções na representatividade (Santos, 1987).

\section{O PT EM 2000}

Os números relativos às eleições municipais de 2000 revelam o PT em situação nitidamente singular no sistema partidário brasileiro. Seu padrão de coligações é único entre os grandes partidos, indicando uma postura diante das eleições em que ocupar espaço e marcar posição - e não só maximizar as chances de vitória - são objetivos relevantes.

A Tabela 1 sumariza os dados gerais dos partidos nas eleições de 2000. O PT apresenta uma capilaridade relativamente baixa, para uma legenda que, há mais de uma década, encarnava a opção de esquerda e o discurso mudancista no país. Disputou as prefeituras em apenas 2.732 municípios (51,9\% do total de 5.263), menos do que o PDT e pouco mais do que o PPS, para citar duas agremiações do campo da esquerda, mas com muito menos peso no cenário nacional.

O que singulariza o PT é, em primeiro lugar, sua disposição para concorrer sozinho às eleições municipais. Com exceção dos dois micropartidos trotskistas, cuja presença na disputa foi mínima (o PSTU esteve presente em apenas 1,6\% dos municípios e o PCO, em 0,3\%), há uma tendência amplamente dominante à realização de coligações, o que é um efeito dos incentivos que a legislação eleitoral brasileira dá à realização desta prática. Quase todos os partidos estão coligados em mais de $90 \%$ das disputas de que participam; as únicas exceções, à parte os trotskistas, são o PMDB e, sobretudo, o PT, que corre sozinho em mais de $28 \%$ das vezes.

Existem fortes oscilações regionais. O PT saiu sozinho com mais freqüência nos dois estados do extremo sul do país $(52,2 \%$ das vezes no 
Um Equilíbrio Delicado: A Dinâmica das Coligações do PT...

Tabela 1

Participação nas Eleições Municipais de 2000, por Partido

\begin{tabular}{|c|c|c|c|c|}
\hline Partido & $\begin{array}{l}\text { Municípios em } \\
\text { Que Concorreu }\end{array}$ & $\begin{array}{l}\text { Concorreu } \\
\text { Sozinho }\end{array}$ & $\begin{array}{c}\text { Ficou com a } \\
\text { Cabeça-de-Chapa }\end{array}$ & $\begin{array}{c}\text { Apoiou Candidatura a } \\
\text { Prefeito de Outro Partido }\end{array}$ \\
\hline PMDB & 5.010 & $662(13,2 \%)$ & $2.182(43,6 \%)$ & $2.166(43,2 \%)$ \\
\hline PFL & 4.665 & $434(9,3 \%)$ & $1.867(40,0 \%)$ & $2.364(50,7 \%)$ \\
\hline PSDB & 4.348 & $381(8,8 \%)$ & $1.700(39,1 \%)$ & 2.267 (52,1\%) \\
\hline PPB & 3.965 & $357(9,0 \%)$ & $1.053(26,6 \%)$ & $2.555(64,4 \%)$ \\
\hline РTB & 3.510 & $204(5,8 \%)$ & $874(24,9 \%)$ & $2.432(69,3 \%)$ \\
\hline PDT & 2.858 & $222(7,8 \%)$ & $682(23,9 \%)$ & $1.954(68,4 \%)$ \\
\hline PT & 2.732 & $770(28,2 \%)$ & $546(20,0 \%)$ & $1.416(51,8 \%)$ \\
\hline PPS & 2.441 & $151(6,2 \%)$ & $483(19,8 \%)$ & $1.807(74,0 \%)$ \\
\hline PL & 2.417 & $128(5,3 \%)$ & $480(19,9 \%)$ & $1.809(74,8 \%)$ \\
\hline PSB & 1.907 & $111(5,8 \%)$ & $370(19,4 \%)$ & $1.426(74,8 \%)$ \\
\hline PSD & 1.360 & $60(4,4 \%)$ & $249(18,3 \%)$ & $1.051(77,3 \%)$ \\
\hline PSC & 1.087 & $56(5,2 \%)$ & $114(10,5 \%)$ & $917(84,4 \%)$ \\
\hline PSL & 766 & $20(2,6 \%)$ & $80(10,4 \%)$ & $666(87,0 \%)$ \\
\hline PV & 740 & $64(8,7 \%)$ & $72(9,7 \%)$ & $604(81,6 \%)$ \\
\hline PC do B & 725 & $14(1,9 \%)$ & $14(1,9 \%)$ & $697(96,1 \%)$ \\
\hline PST & 706 & $29(4,1 \%)$ & $50(7,1 \%)$ & $627(88,8 \%)$ \\
\hline PRP & 693 & $30(4,3 \%)$ & $48(6,9 \%)$ & $615(88,7 \%)$ \\
\hline $\mathrm{PMN}$ & 611 & $28(4,6 \%)$ & $52(8,5 \%)$ & $531(86,9 \%)$ \\
\hline PSDC & 503 & $25(5,0 \%)$ & $43(8,6 \%)$ & $435(86,5 \%)$ \\
\hline PT do B & 429 & $18(4,2 \%)$ & $30(7,0 \%)$ & $381(88,8 \%)$ \\
\hline PRTB & 428 & $32(7,5 \%)$ & $21(4,9 \%)$ & $375(87,6 \%)$ \\
\hline PHS & 366 & $29(7,9 \%)$ & $24(6,6 \%)$ & $313(85,5 \%)$ \\
\hline PTN & 315 & $15(54,8 \%)$ & $9(2,9 \%)$ & $291(92,4 \%)$ \\
\hline PAN & 244 & $21(8,6 \%)$ & $4(1,6 \%)$ & $219(89,8 \%)$ \\
\hline PRN & 227 & $21(9,3 \%)$ & $11(4,9 \%)$ & $195(85,9 \%)$ \\
\hline PGT & 207 & $12(5,85)$ & $2(1,0 \%)$ & $193(93,2 \%)$ \\
\hline PRONA & 132 & $12(9,1 \%)$ & $3(2,3 \%)$ & $117(88,6 \%)$ \\
\hline PSTU & 82 & $46(56,1 \%)$ & $2(2,4 \%)$ & $34(41,5 \%)$ \\
\hline PCB & 69 & $4(5,8 \%)$ & - & $65(94,2 \%)$ \\
\hline PSN & 28 & - & - & $28(100 \%)$ \\
\hline $\mathrm{PCO}$ & 15 & $12(80 \%)$ & - & $3(20 \%)$ \\
\hline Total & 43.586 & $3.968(9,1 \%)$ & $11.065(25,4 \%)$ & $28.553(65,5 \%)$ \\
\hline
\end{tabular}

Fonte: Os autores, a partir dos resultados eleitorais de 2000 fornecidos pelo Tribunal Superior Eleitoral - TSE. 
Rio Grande do Sul; 52,3\%, em Santa Catarina), seguidos de Rondônia $(48,9 \%)$ e Rio Grande do Norte (48,8\%), mas alcançou 100\% de coligações em outros dois pequenos estados do norte, Roraima e Acre.

Mas, quando se coliga, o PT de 2000 apresenta um perfil pouco destoante do restante dos partidos. Como regra geral, quanto maior a capilaridade nacional de um partido - isto é, quanto maior o número de municípios em que ele participa das eleições -, maior a porcentagem de coligações nas quais ele é o cabeça-de-chapa (tem um candidato a prefeito apoiado por outras siglas). O PMDB, que concorre em mais municípios, é o único a ter a cabeça-de-chapa em mais da metade de suas coligações ${ }^{6}$; seguem-se PFL e PSDB, na faixa dos $40 \%$, e assim por diante. Para os 15 maiores partidos da Tabela 1, há uma progressão monótona, com apenas duas exceções. Uma é o PC do B, que possui muito menos cabeças-de-chapa do que seria esperado, além de ter disputado sozinho em poucos municípios - reflexo de sua estratégia "pragmática", que privilegia a obtenção de cadeiras no Poder Legislativo e de postos secundários no Poder Executivo. A outra é o PT, que é apoiado mais vezes do que o previsto, mas nada de especialmente notável: é o cabeça-de-chapa em $27,8 \%$ das coligações de que participa, algo como três pontos percentuais acima do que o modelo sugeriria.

Medida em termos de sucesso eleitoral imediato, a opção do PT nas eleições municipais de 2000 mostrou-se pouco feliz. A Tabela 2 apresenta as vitórias conquistadas pelos partidos mais importantes, definidos como aqueles que participaram das disputas para prefeituras de pelo menos 700 cidades. As porcentagens são calculadas sobre o total de pleitos disputados pelo partido naquela condição (sozinho, coligado etc.), tal como indicado na Tabela 1.

Não é surpreendente que os partidos com maior capilaridade alcancem um índice de sucesso maior nas eleições municipais, uma vez que os pequenos tendem a estar pouco presentes nos municípios menores, com até 5 mil eleitores, onde a disputa é menos intensa. Ainda assim, é notável que o PT mostre uma proporção de vitórias muito inferior à das outras legendas grandes e médias; na verdade, neste quesito, ele só está à frente dos micropartidos da extrema esquerda (PSTU, PCO e PCB). Em relação aos grandes partidos (PMDB, PFL e PSDB), com os quais rivalizava no cenário nacional, chama a atenção o fato de que a diferença no sucesso petista foi maior quando concorreu sozinho e menor quando apoiou candidatos de outros partidos. Isto é, a opção de 
Um Equilíbrio Delicado: A Dinâmica das Coligações do PT...

Tabela 2

Vitórias dos Partidos Que Disputaram as Eleições de 2000

em 700 ou Mais Municípios

\begin{tabular}{|c|c|c|c|c|}
\hline Partido & $\begin{array}{l}\text { Total de } \\
\text { Vitórias } \\
\text { Obtidas }\end{array}$ & $\begin{array}{c}\text { Vitórias nas } \\
\text { Disputas em Que } \\
\text { Concorreu Sozinho }\end{array}$ & $\begin{array}{c}\text { Vitórias nas Dis- } \\
\text { putas em Que } \\
\text { Foi Cabeça- } \\
\text { de-Chapa }\end{array}$ & $\begin{array}{l}\text { Vitórias Apoiando } \\
\text { Candidato a } \\
\text { Prefeito de Outro } \\
\text { Partido } \\
\end{array}$ \\
\hline PMDB & $\begin{array}{c}2.393 \\
(47,8 \%)\end{array}$ & $\begin{array}{c}214 \\
(32,3 \%)\end{array}$ & $\begin{array}{c}1.042 \\
(47,8 \%)\end{array}$ & $\begin{array}{c}1.137 \\
(52,5 \%)\end{array}$ \\
\hline PFL & $\begin{array}{c}2.257 \\
(48,4 \%)\end{array}$ & $\begin{array}{c}139 \\
(32,0 \%)\end{array}$ & $\begin{array}{c}887 \\
(47,5 \%)\end{array}$ & $\begin{array}{c}1.231 \\
(52,1 \%)\end{array}$ \\
\hline PSDB & $\begin{array}{c}2.160 \\
(49,7 \%)\end{array}$ & $\begin{array}{c}104 \\
(27,3 \%)\end{array}$ & $\begin{array}{c}885 \\
(52,1 \%)\end{array}$ & $\begin{array}{c}1.171 \\
(51,7 \%)\end{array}$ \\
\hline РPB & $\begin{array}{c}1.946 \\
(49,1 \%)\end{array}$ & $\begin{array}{c}123 \\
(34,5 \%)\end{array}$ & $\begin{array}{c}495 \\
(47,0 \%)\end{array}$ & $\begin{array}{c}1.328 \\
(52,0 \%)\end{array}$ \\
\hline РТВ & $\begin{array}{c}1.656 \\
(47,2 \%)\end{array}$ & $\begin{array}{c}38 \\
(18,6 \%)\end{array}$ & $\begin{array}{c}360 \\
(41,2 \%)\end{array}$ & $\begin{array}{c}1.258 \\
(51,7 \%)\end{array}$ \\
\hline PDT & $\begin{array}{c}1.207 \\
(42,2 \%)\end{array}$ & $\begin{array}{c}32 \\
(14,4 \%)\end{array}$ & $\begin{array}{c}256 \\
(37,5 \%)\end{array}$ & $\begin{array}{c}919 \\
(47,0 \%)\end{array}$ \\
\hline PPS & $\begin{array}{c}1.062 \\
(43,5 \%)\end{array}$ & $\begin{array}{c}15 \\
(9,8 \%)\end{array}$ & $\begin{array}{c}151 \\
(31,3 \%)\end{array}$ & $\begin{array}{c}896 \\
(49,6 \%)\end{array}$ \\
\hline PL & $\begin{array}{c}1.141 \\
(47,2 \%)\end{array}$ & $\begin{array}{c}17 \\
(13,3 \%)\end{array}$ & $\begin{array}{c}217 \\
(45,2 \%)\end{array}$ & $\begin{array}{c}907 \\
(50,1 \%)\end{array}$ \\
\hline PSB & $\begin{array}{c}788 \\
(41,3 \%)\end{array}$ & $\begin{array}{c}11 \\
(9,9 \%)\end{array}$ & $\begin{array}{c}122 \\
(32,3 \%)\end{array}$ & $\begin{array}{c}655 \\
(45,9 \%)\end{array}$ \\
\hline PT & $\begin{array}{c}754 \\
(27,6 \%)\end{array}$ & $\begin{array}{c}37 \\
(4,8 \%)\end{array}$ & $\begin{array}{c}150 \\
(27,5 \%)\end{array}$ & $\begin{array}{c}567 \\
(40,0 \%)\end{array}$ \\
\hline PSD & $\begin{array}{c}614 \\
(45,2 \%)\end{array}$ & $\begin{array}{c}5 \\
(8,3 \%)\end{array}$ & $\begin{array}{c}106 \\
(42,6 \%)\end{array}$ & $\begin{array}{c}503 \\
(47,9 \%)\end{array}$ \\
\hline PSC & $\begin{array}{c}441 \\
(40,6 \%)\end{array}$ & $\begin{array}{c}3 \\
(5,4 \%)\end{array}$ & $\begin{array}{c}30 \\
(26,3 \%)\end{array}$ & $\begin{array}{c}408 \\
(44,5 \%)\end{array}$ \\
\hline PSL & $\begin{array}{c}324 \\
(43,3 \%)\end{array}$ & - & $\begin{array}{c}26 \\
(32,5 \%)\end{array}$ & $\begin{array}{c}298 \\
(44,7 \%)\end{array}$ \\
\hline PC do B & $\begin{array}{c}262 \\
(36,1 \%)\end{array}$ & - & $\begin{array}{c}1 \\
(7,1 \%)\end{array}$ & $\begin{array}{c}261 \\
(37,5 \%)\end{array}$ \\
\hline PST & $\begin{array}{c}318 \\
(45,0 \%)\end{array}$ & $\begin{array}{c}1 \\
(3,5 \%)\end{array}$ & $\begin{array}{c}15 \\
(30 \%)\end{array}$ & $\begin{array}{c}302 \\
(48,2 \%)\end{array}$ \\
\hline PV & $\begin{array}{c}290 \\
(39,2 \%) \\
\end{array}$ & $\begin{array}{c}1 \\
(1,6 \%) \\
\end{array}$ & $\begin{array}{c}12 \\
(16,7 \%)\end{array}$ & $\begin{array}{c}277 \\
(45,9 \%) \\
\end{array}$ \\
\hline
\end{tabular}

Fonte: Os autores, a partir dos resultados eleitorais de 2000 fornecidos pelo TSE. 
disputar isolado ou de exigir a cabeça-de-chapa não correspondeu a uma avaliação realista das chances de vitória.

Além de participar de menos coligações, o PT participou de coligações menores. Como regra, os partidos menores tendem a integrar coligações maiores - mais uma vez, porque concentram sua participação nos municípios grandes, em que existem mais legendas disponíveis para integrar alianças; e também porque as alianças para as prefeituras costumam ser reproduzidas nas listas para as câmaras de vereadores e, sozinhos, os pequenos partidos raramente conseguem alcançar o quociente eleitoral. Mas as coligações integradas pelos petistas são menores do que se esperaria, reunindo, em média, 2,8 partidos, número superior apenas ao do $\mathrm{PSTU}^{7}$. Apenas para comparação, os números são 2,9 para PMDB ou PFL; 3,1 para PSDB ou PPB; 3,3 para PTB; 3,4 para PPS; 3,7 para PL ou PSB.

Na Tabela 3, é possível verificar quais foram os parceiros do PT em suas coligações. À primeira vista, é notável o ecumenismo: não há legenda com a qual os petistas não tenham, em algum município, se coligado. $\mathrm{O}$ PMDB é o parceiro mais freqüente, reflexo de sua capilaridade superior, mas os dados da tabela deixam claro que os aliados preferenciais do PT são as legendas à esquerda: PDT, PSB, PPS e PC do B.

As diferenças regionais, aqui também, são notáveis. No Rio Grande do Sul, o PDT participou de 67,9\% das coligações integradas pelo PT, mas o PMDB, principal adversário local, não passou de 3,2\%. Já no vizinho estado de Santa Catarina, o PMDB, opositor das oligarquias dominantes abrigadas no PP e PFL, integrou 54,1\% das coligações do PT, número que chega a 63,6\% no Paraná (certamente graças à influência do governador Roberto Requião, que representa a esquerda do PMDB) e a $82,7 \%$ em Tocantins, onde ambos os partidos estão na oposição ao grupo político da família Siqueira Campos. Situações semelhantes explicam a forte presença do PSDB no Acre (participa de 72,7\% das coligações do PT) ou em Roraima (60\%), estados em que, muitas vezes, a linha divisória das opções políticas é o apoio ou o combate ao banditismo.

O principal elemento explicado, porém, parece residir no porte dos municípios, conforme sumarizado na Tabela 4. 
Um Equilíbrio Delicado: A Dinâmica das Coligações do PT...

Tabela 3

Freqüência das Coligações do PT nas Eleições Municipais de 2000

\begin{tabular}{|c|c|c|c|}
\hline Partido & Total & $\begin{array}{c}\text { Porcentagem sobre } \\
\text { o Total de Municípios em } \\
\text { Que o PT Concorreu }\end{array}$ & $\begin{array}{c}\text { Porcentagem sobre o Total de } \\
\text { Municípios em Que o Partido } \\
\text { Coligado Concorreu }\end{array}$ \\
\hline Sem coligação & 770 & 28,2 & - \\
\hline PMDB & 707 & 25,9 & 14,1 \\
\hline PDT & 659 & 24,1 & 23,1 \\
\hline PSB & 594 & 21,7 & 31,1 \\
\hline PPS & 528 & 19,3 & 21,6 \\
\hline PSDB & 454 & 16,6 & 10,4 \\
\hline PC do B & 377 & 13,8 & 52,0 \\
\hline РTB & 300 & 11,0 & 8,5 \\
\hline РPB & 234 & 8,6 & 5,9 \\
\hline PL & 226 & 8,3 & 9,4 \\
\hline PFL & 193 & 7,1 & 4,1 \\
\hline PV & 190 & 7,0 & 25,7 \\
\hline PSD & 141 & 5,2 & 10,4 \\
\hline PSC & 117 & 4,3 & 10,8 \\
\hline PMN & 114 & 4,2 & 18,7 \\
\hline PST & 86 & 3,1 & 12,2 \\
\hline PSL & 82 & 3,0 & 10,7 \\
\hline PHS & 72 & 2,6 & 19,7 \\
\hline PRP & 70 & 2,6 & 10,1 \\
\hline PSDC & 60 & 2,2 & 11,9 \\
\hline PT do B & 49 & 1,8 & 11,4 \\
\hline PCB & 47 & 1,7 & 68,1 \\
\hline PTN & 43 & 1,6 & 13,7 \\
\hline PAN & 37 & 1,4 & 15,2 \\
\hline PSTU & 35 & 1,3 & 42,7 \\
\hline PGT & 29 & 1,1 & 14,0 \\
\hline PRTB & 23 & 0,8 & 5,4 \\
\hline PRN & 13 & 0,5 & 5,7 \\
\hline Prona & 11 & 0,4 & 8,3 \\
\hline PSN & 5 & 0,2 & 17,9 \\
\hline $\mathrm{PCO}$ & 2 & 0,1 & 13,3 \\
\hline
\end{tabular}

Fonte: Os autores, a partir dos resultados eleitorais de 2000 fornecidos pelo TSE. 
Tabela 4

Coligações do PT nas Eleições de 2000, por Porte do Município

(\%)

\begin{tabular}{l|c|c|c|c|c|c}
\hline & $\begin{array}{c}\text { Menos de } \\
\mathbf{5 . 0 0 0} \text { Eleitores }\end{array}$ & $\begin{array}{c}\text { De 5.000 } \\
\text { a } \mathbf{1 0 . 0 0 0}\end{array}$ & $\begin{array}{c}\text { De 10.001 } \\
\text { a 50.000 }\end{array}$ & $\begin{array}{l}\text { De 50.001 } \\
\text { a 100.000 }\end{array}$ & $\begin{array}{c}\text { De 100.001 } \\
\text { a 500.000 }\end{array}$ & $\begin{array}{c}\text { Mais de } \\
\mathbf{5 0 0 . 0 0 0}\end{array}$ \\
\hline Sem coligações & 31,4 & 28,4 & 29,9 & 17,5 & 10,8 & - \\
PMDB & 34,1 & 28,3 & 23,1 & 13,3 & 10,8 & - \\
PDT & 22,8 & 23,6 & 25,1 & 23,8 & 26,7 & 15,4 \\
PSB & 10,4 & 17,3 & 27,4 & 35,0 & 36,7 & 53,9 \\
PPS & 12,2 & 19,8 & 21,6 & 26,6 & 23,3 & 38,5 \\
PSDB & 19,7 & 18,2 & 15,6 & 11,2 & 9,2 & - \\
PC do B & 1,8 & 4,1 & 16,1 & 47,6 & 65,0 & 84,6 \\
PTB & 11,6 & 12,9 & 10,5 & 8,4 & 5,8 & - \\
PPB & 11,0 & 10,3 & 7,5 & 4,2 & 1,7 & - \\
PFL & 11,0 & 6,6 & 6,3 & 2,8 & 0,8 & - \\
\hline
\end{tabular}

Fonte: Os autores, a partir dos resultados eleitorais de 2000 fornecido pelo TSE.

Como esperado, quanto maior o município, mais as coligações se guiam por critérios de coerência ideológica ou se vinculam às alianças políticas nacionais. É o efeito da maior "sofisticação" do eleitorado dos grandes centros ou, dito de outra forma, do fato de, diante de um jogo político mais complexo e da maior distância que o separa dos líderes partidários e dos problemas em pauta, este eleitorado tornar-se mais dependente do balizamento fornecido por noções abstratas como esquerda e direita ou governo e oposição.

As coligações do PT com legendas ao centro e à direita no espectro partidário estão concentradas nos municípios pequenos, ao passo que PC do B, PSB e PPS são, de longe, os parceiros preferenciais nos grandes centros (acima de 100 mil eleitores) e mesmo nas cidades de porte médio (entre 50 mil e 100 mil eleitores). O PC do B, em particular, pouco presente nos pequenos municípios devido à baixa capilaridade de seus diretórios, é parceiro constante nas metrópoles, refletindo sua vinculação eleitoral, já desde há alguns anos, ao petismo, do qual tende a se tornar um satélite.

A fim de facilitar a visualização dos dados, os partidos foram alocados em três grandes grupos ideológicos, seguindo a divisão corrente na ciência política brasileira. À esquerda, ao lado do PT, estão PCB, PC do B, PCO, PDT, PHS, PMN, PPS, PSB, PSTU e PV. No centro, PMDB e 
PSDB. À direita, PFL, PL, PPB e PTB, além de uma miríade de micropartidos (PAN, PGT, PRN, Prona, PRTB, PSC, PSD, PSDC, PSL, PSN, PST, PT do B e PTN). Atribuído o valor +1 para cada coligação feita com partido de direita, 0 para coligações com partidos de centro e -1 para coligações com partidos de esquerda, calcula-se um "índice de viés ideológico das coligações", que é o somatório desses valores dividido pelo número total de coligações realizadas ${ }^{8}$. Assim, o índice tem como valores extremos +1 (correspondendo a alianças realizadas exclusivamente à direita do espectro político) e -1 (coligações só com partidos de esquerda).

O valor médio das coligações do PT em 2000 ficou em -0,165, o que representa uma posição ligeiramente à esquerda do centro do espectro político. No entanto, este valor esconde profundas diferenças regionais. O coeficiente de variação entre os estados chegou a $81,84 \%$. O Rio Grande do Sul apresenta um índice de -0,892, o que coloca o PT local fazendo alianças quase que exclusivamente à esquerda; segue-se o Acre, com -0,639. Não por acaso, são (ao lado do Mato Grosso do Sul) estados cujos governos, na época, o PT controlava. Se o perfil do diretório gaúcho ajuda a explicar o viés à esquerda, no caso acreano é mais plausível julgar que a presença no governo estadual contribuiu para que os aliados tradicionais do PT se organizassem para disputar as eleições em mais municípios. Assim, nos 22 municípios acreanos, o PC do B concorreu em 15; o PPS, em 14; e o PSB em 13 - em quase todos os casos, coligados ao PT.

No extremo oposto, o Amazonas, com índice igual a +0,221, mostra um perfil de coligações mais próximo da centro-direita. A maior parte dos estados (18 em 26) concentra-se do centro para a esquerda, na faixa de viés ideológico situada entre $-0,4$ e $+0,1$; é o caso de São Paulo $(-0,298)$, Rio de Janeiro $(-0,171)$ e Minas Gerais $(+0,046)$.

Quando a atenção se desloca para o porte dos municípios, fica evidente o peso da coerência ideológica nas maiores cidades. Nos municípios com menos de 5 mil eleitores, até por falta de parceiros disponíveis entre os partidos menores de esquerda, as coligações do PT alcançam um índice de $+0,029$, quase no exato centro. A partir daí, há um deslocamento linear para a esquerda. Nas metrópoles com mais de 500 mil eleitores, o PT fez ao todo 47 alianças, incluindo apenas cinco partidos de direita, o que resultou em um índice de -0,787. Mesmo nas cidades com 
de 100 mil a 500 mil eleitores, o índice, de - 0,508 , já situa as coligações com clareza no campo da esquerda.

Do ponto de vista do rendimento eleitoral, a abertura às coligações com partidos de direita mostrou-se mais bem-sucedida. Enquanto o índice de viés ideológico geral das coligações do PT é de -0,165, a média das coligações vitoriosas fica em -0,065. Para qualquer faixa de porte do município, o índice das coligações vitoriosas apresenta-se mais à direita, em uma diferença que não chega a ser gigantesca, mas tampouco é desprezível, oscilando entre 0,043 e 0,193.

Um segundo índice permite apreciar outro aspecto da estratégia eleitoral do PT nas eleições de 2000. Atribuiu-se o valor +1 para os partidos que compunham a base de sustentação do governo federal, identificados como PSDB, PFL, PMDB, PTB e PPB, e o valor -1 para os partidos de oposição ao governo federal (PT, PSB, PC do B, PDT, PV, PTN, PHS, PST, PL, PSL, PCB, PSTU, PCO e Prona). Valeu, assim, a posição oficial de cada diretório nacional à época das eleições. Os demais partidos, todos pequenos, sem relevância na política nacional, apresentam posição neutra ou ambígua em relação ao governo Lula e foram excluídos da base de cálculo9. No caso das eleições de 2000, os dois índices tendem a coincidir, já que todos os partidos à esquerda faziam oposição ao governo de Fernando Henrique Cardoso. Ainda assim, é de notar que o viés de oposição, nas coligações do $\mathrm{PT}$, tende a ser um pouco maior do que o viés de esquerda.

O "índice de governismo das coligações" em 2000 alcança uma média nacional de -0,220, oscilando, nos estados, entre -0,867 (no Rio Grande do Sul) e $+0,231$ (em Tocantins). A maior parte (18 dos 26 estados) fica no intervalo entre $-0,1$ e $-0,7$. O peso do alinhamento ao governo federal na composição das coligações fica evidente quando os municípios são divididos por porte. Naqueles com mais de 500 mil eleitores, as coligações são perfeitamente oposicionistas, alcançando o índice de -1; mesmo quando o eleitorado fica nas faixas anteriores, o índice é muito elevado, chegando a $-0,798$ (entre 100 mil e 500 mil eleitores) e a -0,675 (50 mil a 100 mil eleitores).

Como o Gráfico 1 indica, há uma forte correlação entre os índices de governismo e de viés ideológico. O PT de 2000 situa-se claramente no lado da oposição, ao escolher seus parceiros; e também na esquerda. As diferenças estaduais existem, mas o único estado que ocupa uma posi- 
Gráfico 1

Índice de Viés Ideológico e Índice de Governismo das Coligações

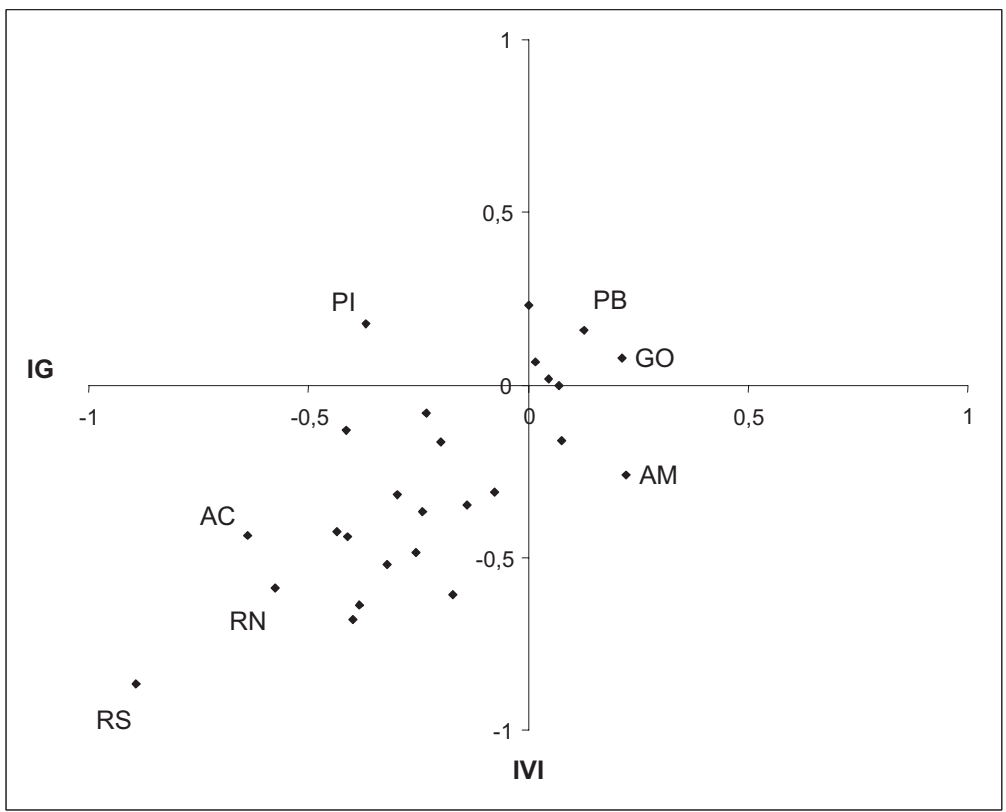

Fonte: Os autores, a partir dos resultados eleitorais de 2000 fornecidos pelo TSE.

ção claramente discrepante é o Rio Grande do Sul, no canto inferior esquerdo do gráfico.

Com base nos dados apresentados, pode-se dizer que o PT possui, nitidamente, um comportamento diferenciado no que se refere à estratégia partidária para as eleições. Devido à sua capilaridade relativamente baixa, esperar-se-ia, tendo em vista as regras eleitorais, a realização do maior número possível de coligações para aumentar sua representação. Trata-se de um dos fatores que favorecem a vitória de um partido, sendo que, no caso do PT, sua taxa de sucesso ao concorrer sozinho $-4,81 \%$ - é bastante inferior à taxa de quando apoiado por outros partidos $-27,47 \%$.

A baixa quantidade de coligações não se explica, assim, por uma lógica eleitoral imediatista. Ela reflete uma estratégia de médio prazo, focada na construção de uma marca político-partidária distinta, capaz de credenciar o PT diante da fatia do eleitorado que buscava comportamentos diferenciados da política tradicional. 


\section{O PT EM 2004}

Em 2004, o PT apresentou uma capilaridade muito maior do que quatro anos antes. Disputou as prefeituras em 4.741 municípios, um salto de $73,5 \%$ em relação às eleições de 2000 . Seus parceiros no governo federal também se fizeram bem mais presentes; o PTB disputou em 4.261 municípios (21,4\% a mais); o PL, em 3.930 (62,6\% a mais); o PPS, em 3.373 (38,2\% a mais); o PSB, em 2.655 (39,2\% a mais); o PC do B, em 1.366 (88,4\% a mais). Já o PMDB permaneceu praticamente estável, até por faltar espaço para crescimento, participando das eleições em 5.088 municípios (1,6\% a mais), o mesmo ocorrendo com o PSDB, presente em 4.564 municípios ( $5 \%$ a mais), enquanto o PFL, que disputou as prefeituras de 4.414 cidades, sofria um pequeno decréscimo (de 5,4\%).

Como regra, em todo o país, o PT de 2004 mostrou-se um partido aberto a coligações. Concorreu sozinho em apenas 737 municípios, isto é, $15,6 \%$ das vezes, contra $28,8 \%$ em 2000 . Regionalmente, as oscilações no número de candidaturas isoladas do PT foram atenuadas, permanecendo Santa Catarina, Rondônia e Rio Grande do Sul os estados nos quais o PT concorre sozinho mais vezes - 31,95\%, 23,08\% e 21,41\%, respectivamente. Em $58,8 \%$ das vezes, o PT sustentou chapas encabeçadas por legendas aliadas; e nos outros $25,6 \%$, seus candidatos foram apoiados por outros partidos. Apesar disto, ele se manteve como o partido com menor taxa de coligações, à exceção do PCO e do PSTU.

Ocorreu um crescimento razoável do número de prefeitos eleitos pelo PT, saindo de 187 em 2000 para 411 em 2004, um aumento de pouco mais de $100 \%$. Mas, apesar do crescimento, a porcentagem de vitórias do PT ainda permanece abaixo das taxas de sucesso alcançadas pelos grandes partidos. Como se pode constatar pela Tabela 5, enquanto partidos como PMDB, PSDB, PTB e PP mantêm uma porcentagem de $40 \%$ de vitórias sobre suas participações o PT obtém $34,1 \%$ de vitórias. Um dos fatores que pode contribuir para esta situação é a dificuldade com que o PT consegue obter vitórias isoladamente. Ganhou em menos de $6 \%$ das vezes em que concorreu sozinho, contra mais de $30 \%$ do PMDB ou mais de $20 \%$ do PFL ou PSDB ${ }^{10}$.

Ao se observar o número de vitórias do PT, em conjunto com o aumento da sua participação nas eleições municipais, constata-se haver alguma relação entre o número de exposições à disputa eleitoral e a melhoria da taxa de sucesso eleitoral. Algumas explicações podem ser aventadas. 
Um Equilíbrio Delicado: A Dinâmica das Coligações do PT...

Tabela 5

Vitórias dos Partidos Que Disputaram as Eleições de 2004

em 900 ou Mais Municípios

\begin{tabular}{|c|c|c|c|c|}
\hline Partido & $\begin{array}{c}\text { Total de Vitórias } \\
\text { Obtidas }\end{array}$ & $\begin{array}{c}\text { Vitórias nas } \\
\text { Disputas em Que } \\
\text { Concorreu } \\
\text { Sozinho }\end{array}$ & $\begin{array}{c}\text { Vitórias nas } \\
\text { Disputas em } \\
\text { Que Foi } \\
\text { Cabeça-de-Chapa }\end{array}$ & $\begin{array}{l}\text { Vitórias Apoiando } \\
\text { Candidato a } \\
\text { Prefeito de Outro } \\
\text { Partido }\end{array}$ \\
\hline PMDB & $\begin{array}{c}2.243 \\
(44,8 \%)\end{array}$ & $\begin{array}{c}102 \\
(31,78 \%)\end{array}$ & $\begin{array}{c}954 \\
(44,19 \%)\end{array}$ & $\begin{array}{c}1.187 \\
(45,51 \%)\end{array}$ \\
\hline PFL & $\begin{array}{c}2.213 \\
(50,14 \%)\end{array}$ & $\begin{array}{c}42 \\
(20,69 \%)\end{array}$ & $\begin{array}{c}750 \\
(48,26 \%)\end{array}$ & $\begin{array}{c}1.421 \\
(53,48 \%)\end{array}$ \\
\hline PSDB & $\begin{array}{c}2.194 \\
(48,07 \%)\end{array}$ & $\begin{array}{c}42 \\
(22,34 \%)\end{array}$ & $\begin{array}{c}829 \\
(47,92 \%)\end{array}$ & $\begin{array}{c}1.323 \\
(50,00 \%)\end{array}$ \\
\hline РTB & $\begin{array}{c}1.971 \\
(46,26 \%)\end{array}$ & $\begin{array}{c}20 \\
(17,39 \%)\end{array}$ & $\begin{array}{c}403 \\
(41,21 \%)\end{array}$ & $\begin{array}{c}1.548 \\
(48,86 \%)\end{array}$ \\
\hline PP & $\begin{array}{c}2.032 \\
(47,29 \%)\end{array}$ & $\begin{array}{c}33 \\
(17,65 \%)\end{array}$ & $\begin{array}{c}518 \\
(47,96 \%)\end{array}$ & $\begin{array}{c}1.481 \\
(48,88 \%)\end{array}$ \\
\hline PT & $\begin{array}{c}1.617 \\
(34,11 \%)\end{array}$ & $\begin{array}{c}44 \\
(5,97 \%)\end{array}$ & $\begin{array}{c}367 \\
(30,21 \%)\end{array}$ & $\begin{array}{c}1.206 \\
(43,24 \%)\end{array}$ \\
\hline PL & $\begin{array}{c}1.823 \\
(46,39 \%)\end{array}$ & $\begin{array}{c}12 \\
(9,38 \%)\end{array}$ & $\begin{array}{c}371 \\
(41,04 \%)\end{array}$ & $\begin{array}{c}1.440 \\
(49,69 \%)\end{array}$ \\
\hline PDT & $\begin{array}{c}1.604 \\
(44,35 \%)\end{array}$ & $\begin{array}{c}16 \\
(9,58 \%)\end{array}$ & $\begin{array}{c}290 \\
(42,15 \%)\end{array}$ & $\begin{array}{c}1.298 \\
(46,99 \%)\end{array}$ \\
\hline PPS & $\begin{array}{c}1.514 \\
(44,89 \%)\end{array}$ & $\begin{array}{c}10 \\
(7,52 \%)\end{array}$ & $\begin{array}{c}295 \\
(38,97 \%)\end{array}$ & $\begin{array}{c}1.209 \\
(48,69 \%)\end{array}$ \\
\hline PSB & $\begin{array}{c}1.130 \\
(42,56 \%)\end{array}$ & $\begin{array}{c}7 \\
(5,69 \%)\end{array}$ & $\begin{array}{c}168 \\
(33,80 \%)\end{array}$ & $\begin{array}{c}955 \\
(46,93 \%)\end{array}$ \\
\hline PV & $\begin{array}{c}758 \\
(41,17 \%)\end{array}$ & $\begin{array}{c}3 \\
(2,65 \%)\end{array}$ & $\begin{array}{c}54 \\
(29,83 \%)\end{array}$ & $\begin{array}{c}701 \\
(45,31 \%)\end{array}$ \\
\hline PSC & $\begin{array}{c}713 \\
(42,69 \%)\end{array}$ & - & $\begin{array}{c}26 \\
(20,31 \%)\end{array}$ & $\begin{array}{c}687 \\
(46,11 \%)\end{array}$ \\
\hline PC do B & $\begin{array}{c}509 \\
(37,26 \%)\end{array}$ & - & $\begin{array}{c}10 \\
(16,13 \%)\end{array}$ & $\begin{array}{c}499 \\
(39,57 \%)\end{array}$ \\
\hline PSL & $\begin{array}{c}561 \\
(43,56 \%)\end{array}$ & $\begin{array}{c}4 \\
(9,52 \%)\end{array}$ & $\begin{array}{c}21 \\
(25,30 \%)\end{array}$ & $\begin{array}{c}536 \\
(46,09 \%)\end{array}$ \\
\hline PMN & $\begin{array}{c}508 \\
(41,13 \%)\end{array}$ & - & $\begin{array}{c}31 \\
(29,81 \%)\end{array}$ & $\begin{array}{c}477 \\
(44,04 \%)\end{array}$ \\
\hline PRP & $\begin{array}{c}504 \\
(42,28 \%)\end{array}$ & $\begin{array}{c}2 \\
(5,88 \%)\end{array}$ & $\begin{array}{c}35 \\
(30,70 \%)\end{array}$ & $\begin{array}{c}467 \\
(44,73 \%)\end{array}$ \\
\hline PSDC & $\begin{array}{c}448 \\
(41,10 \%)\end{array}$ & $\begin{array}{c}1 \\
(1,82 \%)\end{array}$ & $\begin{array}{c}12 \\
(16,44 \%)\end{array}$ & $\begin{array}{c}435 \\
(45,22 \%)\end{array}$ \\
\hline PHS & $\begin{array}{c}405 \\
(38,14 \%)\end{array}$ & $\begin{array}{c}4 \\
(5,80 \%)\end{array}$ & $\begin{array}{c}22 \\
(30,56 \%)\end{array}$ & $\begin{array}{c}379 \\
(41,15 \%)\end{array}$ \\
\hline
\end{tabular}

Fonte: Os autores, a partir dos resultados eleitorais de 2004 fornecidos pelo TSE. 
A primeira é que a participação em locais não explorados politicamente - ao menos no que concerne ao Executivo municipal - pode ter permitido aflorar um apoio político potencial. A segunda deriva da posição de poder ocupada pelo PT, uma vez que ser o detentor do Poder Executivo federal lhe possibilitou uma mobilização de recursos muito maior do que nos anos precedentes.

Em média, o PT de 2004 aliou-se a 2,92 outros partidos para disputar as eleições, mas existem fortes oscilações regionais. A média de coligações tende a ser maior em estados com menor eleitorado, como Amazonas $(4,93)$; Roraima $(4,69)$; Amapá $(4,47)$; e Espírito Santo $(4,61)$, mas atinge um número elevado também no Rio de Janeiro $(4,3)$. É menor nos dois estados do extremo sul, Santa Catarina $(1,55)$ e Rio Grande do Sul $(1,85)$, seguidos por São Paulo $(2,59)$. Há indícios de que a tendência a participar de coligações maiores é influenciada pelo zelo ideológico: quanto mais o PT procura manter sua identidade de esquerda, menor o arco de alianças. A correlação entre o índice de viés ideológico das coligações e o número de coligações não foi especialmente impactante, mas tampouco é desprezível, ficando em 0,36.

No entanto, o PT ainda apresenta uma média de coligações significativamente inferior às dos outros partidos brasileiros. Seus 2,92 estão acima apenas das duas legendas da extrema esquerda, o PSTU (média de 0,26 coligações por município em que disputou) e o PCO $(2,52)^{11}$. Os outros micropartidos, que buscam maximizar suas chances eleitorais e raras vezes se arriscam a disputar sozinhos, possuem médias muito elevadas, em geral acima de 5 ou até de 6. De fato, também em 2004, como regra geral, quanto menor a legenda, maior o número médio de coligações realizadas. Mas é importante observar que mesmo os outros grandes partidos - PMDB, PSDB, PFL e PP - apresentam médias de coligações bastante acima do PT, girando em torno de 3,75 (ver Tabela 6). Todos eles apresentam oscilações significativas, de estado para estado; e em todos eles, também, os dois estados do extremo sul estão entre aqueles com as médias de coligações mais baixas.

De volta aos dados relativos ao PT, a média de coligações tende a aumentar de acordo com o tamanho do município, passando de um mínimo de 2,49 coligações nos municípios com menos de 5 mil eleitores a 4,33 nos municípios com mais de 500 mil eleitores (o pico está na categoria anterior, com 4,73 coligações em média nos municípios entre 100 mil e 500 mil eleitores). O dado reflete, em grande medida, a maior dis- 
Um Equilíbrio Delicado: A Dinâmica das Coligações do PT...

Tabela 6

Média de Coligações nas Eleições de 2004, por Partido

\begin{tabular}{|c|c|}
\hline Partido & Média de Coligações \\
\hline Prona & 6,27 \\
\hline PAN & 6,18 \\
\hline PTN & 5,92 \\
\hline PT do B & 5,71 \\
\hline PRTB & 5,7 \\
\hline PTC & 5,65 \\
\hline PSL & 5,53 \\
\hline PCB & 5,45 \\
\hline $\mathrm{PMN}$ & 5,41 \\
\hline PSDC & 5,33 \\
\hline PRP & 5,32 \\
\hline PHS & 5,29 \\
\hline PSC & 5,26 \\
\hline PV & 4,86 \\
\hline PC do B & 4,78 \\
\hline PSB & 4,28 \\
\hline PPS & 4,19 \\
\hline PL & 4,15 \\
\hline PDT & 4,11 \\
\hline РTB & 4,06 \\
\hline $\mathrm{PP}$ & 3,92 \\
\hline PSDB & 3,75 \\
\hline PFL & 3,74 \\
\hline PMDB & 3,51 \\
\hline PT & 2,92 \\
\hline $\mathrm{PCO}$ & 2,52 \\
\hline PSTU & 0,26 \\
\hline
\end{tabular}

Fonte: Os autores, a partir dos resultados eleitorais de 2004 fornecidos pelo TSE.

ponibilidade de parceiros nos municípios maiores, que em geral contam com mais partidos organizados localmente, mas também a maior valoração da vitória nestes locais por parte da cúpula petista, que incentivaria a formação de alianças com maior viabilidade eleitoral. Por 
outro lado, as chances de êxito do PT aumentavam com a ampliação das coligações. O partido obteve êxito em $35,4 \%$ das disputas municipais de que participou, proporção que desce a $11,2 \%$ quando são isoladas aquelas em que disputou sozinho. Na média, as chapas vitoriosas integradas pelo PT reuniam 4,04 partidos, ao passo que as derrotadas incluíam 2,31 legendas. O dado é mais significativo quando se leva em conta que foi nos pequenos municípios (nos quais as coligações tendem a ser mais restritas) que o PT obteve seu melhor desempenho: foi vitorioso na disputa de $40,6 \%$ das prefeituras pequenas (com menos de 5 mil eleitores) a que concorreu, contra apenas $27,8 \%$ nos municípios maiores (com mais de 500 mil eleitores). A cobertura do programa Bolsa Família, principal política de atendimento à população mais pobre do governo Lula, pode ter contribuído para esta expansão do Partido dos Trabalhadores nos menores municípios (Nicolau e Peixoto, 2007).

O arco de alianças foi eclético o suficiente para incluir todos os partidos políticos. Mais uma vez, o parceiro mais freqüente foi o PMDB, com o qual o PT esteve unido em 1.579 municípios, ou 33,3\% daqueles em que disputou. Em grande medida, o dado reflete a maior capilaridade do PMDB, que assim estava disponível para alianças em mais localidades. A evolução em relação a 2000 (quando o PT se associou ao PMDB em $25,9 \%$ dos municípios nos quais concorreu), porém, é pequena, quando se lembra que, antes, os dois partidos estavam em lados opostos do eixo governo/oposição e, em 2004, estavam juntos. O PC do B, por sua vez, foi parceiro do PT em apenas $16,2 \%$ das disputas, mas estas 768 coligações correspondem a mais da metade dos municípios em que os pecedobistas estiveram presentes.

A Tabela 7 indica a freqüência de alianças do PT com os diversos partidos da política nacional. São significativas as coligações com legendas de oposição ao governo (PSDB), claramente identificadas com posições de direita (PP) ou ambos (PFL).

A comparação entre as Tabelas 3, com dados das eleições de 2000, e 7, com dados das eleições de 2004, revela o peso do apoio ao governo Lula na política de alianças do PT. Como é natural, os partidos maiores, presentes em mais municípios, são parceiros mais freqüentes. Mas, entre estes, ganham peso legendas como PTB (sétimo maior parceiro em 2000, segundo, em 2004) e PL (nono maior parceiro em 2000, quinto, em 2004), situadas à direita, mas que sustentavam o governo federal. A variável ideológica permanece atuante, sobretudo quando o foco é deslo- 
Um Equilíbrio Delicado: A Dinâmica das Coligações do PT...

Tabela 7

Freqüência das Coligações do PT nas Eleições Municipais de 2004

\begin{tabular}{|c|c|c|c|}
\hline Partido & Total & $\begin{array}{l}\text { Porcentagem sobre o } \\
\text { Total de Municípios em } \\
\text { Que o PT Concorreu }\end{array}$ & $\begin{array}{c}\text { Porcentagem sobre o Total de } \\
\text { Municípios em Que o Partido } \\
\text { Coligado Concorreu }\end{array}$ \\
\hline PMDB & 1.580 & 33,3 & 31,1 \\
\hline РТВ & 1.159 & 24,4 & 27,2 \\
\hline PPS & 1.129 & 23,8 & 33,5 \\
\hline PDT & 1.117 & 23,6 & 30,9 \\
\hline PL & 1.085 & 22,9 & 27,6 \\
\hline PSB & 1.026 & 21,6 & 38,6 \\
\hline PP & 942 & 19,9 & 21,9 \\
\hline PSDB & 934 & 19,7 & 20,5 \\
\hline PC do B & 768 & 16,2 & 56,2 \\
\hline Sem coligação & 737 & 15,5 & - \\
\hline PFL & 704 & 14,8 & 15,9 \\
\hline PV & 511 & 10,8 & 27,8 \\
\hline PMN & 382 & 8,1 & 30,9 \\
\hline PSC & 367 & 7,7 & 22,0 \\
\hline PSL & 281 & 5,9 & 21,8 \\
\hline PHS & 268 & 5,7 & 25,2 \\
\hline PRP & 242 & 5,1 & 20,3 \\
\hline PSDC & 238 & 5,0 & 21,8 \\
\hline PT do B & 205 & 4,3 & 23,0 \\
\hline PTC & 198 & 4,2 & 21,2 \\
\hline PRTB & 184 & 3,9 & 19,8 \\
\hline PTN & 175 & 3,7 & 19,7 \\
\hline PAN & 146 & 3,1 & 22,4 \\
\hline РCB & 96 & 2,0 & 51,1 \\
\hline Prona & 92 & 1,9 & 19,5 \\
\hline PCO & 6 & 0,1 & 13,0 \\
\hline PSTU & 2 & 0,0 & 1,8 \\
\hline
\end{tabular}

Fonte: Os autores, a partir dos resultados eleitorais de 2004 fornecidos pelo TSE.

cado para as legendas de oposição, o que ajuda a explicar o perfil diferente do PSDB, partido de centro, com o qual os petistas se coligam mais vezes se comparado com o do PFL, de direita. A redução da distância entre a proporção de coligações feitas com o PSDB e com o PFL, entre 2000 e 2004, é sobretudo um efeito da maior capilaridade do PT, 
que participou de mais disputas por prefeituras menores, nas quais as questões ideológicas tendem a ser irrelevantes.

Por outro lado, o comportamento das microlegendas de direita - que antes incluíam o PT em algo como $5 \%$ a $10 \%$ de suas coligações, proporção que passa para cerca de $20 \%$ em 2004 - mostra que, no governo, o partido se tornou um parceiro mais interessante.

As oscilações regionais são fortes. As condições da política local explicam por que, no Rio Grande do Sul, são significativamente menores as taxas de aliança com o PFL (5,2\%); o PSDB (8,6\%); o PL (9,1\%); o PPS $(9,9 \%)$ e mesmo o PMDB $(25,1 \%)$, ao passo que desponta como parceiro preferencial o PDT (41,3\%). Na Bahia, a baixa presença de coligações com o PFL $(2,2 \%)$ é compreensível à luz da rejeição do petismo local à figura de Antônio Carlos Magalhães. O principal elemento explicativo, porém, mais uma vez parece residir no porte dos municípios, conforme sumarizado na Tabela 8 .

Tabela 8

Coligações do PT nas Eleições de 2004, por Porte do Município

(\%)

\begin{tabular}{l|c|c|c|c|c|c}
\hline & $\begin{array}{c}\text { Menos de 5.000 } \\
\text { Eleitores }\end{array}$ & $\begin{array}{c}\text { De 5.000 a } \\
\mathbf{1 0 . 0 0 0}\end{array}$ & $\begin{array}{c}\text { De 10.001 } \\
\text { a 50.000 }\end{array}$ & $\begin{array}{c}\text { De 50.001 } \\
\text { a 100.000 }\end{array}$ & $\begin{array}{c}\text { De 100.001 } \\
\text { a 500.000 }\end{array}$ & $\begin{array}{c}\text { Mais de } \\
\mathbf{5 0 0 . 0 0 0}\end{array}$ \\
\hline PMDB & 40,8 & 35,1 & 28,5 & 19,6 & 13,7 & 11,1 \\
PTB & 24,8 & 26,3 & 23,3 & 17,4 & 25,2 & 38,9 \\
PPS & 20,9 & 24,4 & 25,4 & 28,8 & 25,2 & 11,1 \\
PDT & 24,4 & 23,1 & 24,2 & 17,9 & 22,1 & - \\
PL & 23,5 & 23,0 & 22,0 & 18,5 & 29,8 & 38,9 \\
PSB & 14,2 & 19,0 & 27,9 & 32,6 & 36,6 & 27,8 \\
PP & 23,3 & 18,8 & 18,9 & 15,2 & 10,7 & 5,6 \\
PSDB & 22,4 & 21,9 & 17,3 & 14,1 & 8,4 & - \\
PC do B & 4,4 & 10,1 & 22,4 & 54,3 & 67,9 & 83,3 \\
Sem & & & & & & \\
coligações & 13,6 & 18,5 & 16,2 & 13,0 & 6,9 & 5,6 \\
PFL & 19,3 & 15,4 & 12,3 & 6,5 & 5,3 & - \\
\hline
\end{tabular}

Fonte: Os autores, a partir dos resultados eleitorais de 2004 fornecidos pelo TSE.

Da mesma forma que, nas eleições de 2000, quanto maior o município, maior a coerência dos parceiros, tanto em termos do perfil ideológico quanto do alinhamento ao governo federal. Entre os partidos maiores, os aliados à direita no governo Lula, PLe PTB, despontam como princi- 
pais coligados nas grandes cidades, seguidos pelo PSB, também da base de sustentação do governo federal, mas à esquerda. Partidos de oposição (PSDB, PFL e PDT) simplesmente não se coligam com o PT nos municípios com mais de meio milhão de eleitores (embora, em relação a 2000, seja notável a maior abertura dos petistas a coligações com o PFL nos municípios entre 100 mil e 500 mil eleitores). Em posição intermediária, PPS, PMDB e PP revelam as ambigüidades de sua relação com o governo federal.

O índice de viés ideológico mostra de maneira mais sintética a evolução das coligações do PT no espectro esquerda-direita. De um índice de $-0,165$ em 2000, o partido passa para $+0,052$ em 2004, o que significa que a média de suas coligações se coloca (muito) ligeiramente à direita do centro. Isto é, em 2004, o PT optou por coligações mistas, reunindo parceiros à esquerda e à direita. A Tabela 9 revela que, mesmo em estados considerados mais rigorosos ideologicamente, como Rio Grande do Sul e Santa Catarina, o viés à esquerda é bastante tênue. Em apenas um estado, o Acre, o índice mostra os petistas ancorados firmemente na centro-esquerda; e em outro estado da Região Norte, Roraima, o viés pode ser indicado como de centro-direita. No restante do país, o viés das coligações oscila pouco, entre $-0,216$ e $+0,206$, alcançando uma média zero quase perfeita em São Paulo e não se afastando muito disso (com uma levíssima inclinação mais à direita) no cômputo geral.

Com exceção de Goiás e do Amazonas, em todos os estados o PT fez em 2004 um perfil de coligações mais à direita do que em 2000, com o deslocamento sendo mais intenso em estados tão díspares como o Rio Grande do Sul, Rio Grande do Norte e Amapá. A correlação entre os índices das duas eleições é alta $(0,77)$, mostrando que as discrepâncias se devem a composições diferenciadas das direções petistas e a peculiaridades da política local. Nacionalmente, as opções se tornaram um pouco mais homogêneas, com o desvio-padrão caindo de 0,267 para 0,157.

Mais uma vez, o quadro fica mais nítido quando é introduzida a variável porte do município, conforme a Tabela 10 mostra. Embora, em todos os casos, o índice gire em torno do zero, o PT se abre mais para coligações à direita nos menores municípios - e a diferença é mais relevante quando se lembra que, em boa parte destes, as microlegendas, que são majoritariamente de direita, não se encontram organizadas. É possível adiantar uma hipótese para explicar a propensão de coligações mais à esquerda nos municípios de porte médio para grande (de 50.001 
Tabela 9

Índice de Viés Ideológico das Coligações do PT nas

Eleições de 2000 e 2004, por Estado

\begin{tabular}{l|c|c}
\hline Estado & $\mathbf{2 0 0 0}$ & $\mathbf{2 0 0 4}$ \\
\hline Rio Grande do Sul & $-0,892$ & $-0,158$ \\
Santa Catarina & $-0,415$ & $-0,043$ \\
Paraná & $+0,017$ & $+0,114$ \\
São Paulo & $-0,298$ & $+0,002$ \\
Rio de Janeiro & $-0,171$ & $+0,051$ \\
Minas Gerais & $+0,046$ & $+0,165$ \\
Espírito Santo & $-0,242$ & $-0,014$ \\
Mato Grosso do Sul & $-0,076$ & $+0,039$ \\
Mato Grosso & $-0,233$ & $+0,121$ \\
Goiás & $+0,214$ & $+0,208$ \\
Bahia & $-0,435$ & $-0,071$ \\
Sergipe & $-0,139$ & $+0,134$ \\
Alagoas & $-0,256$ & $+0,103$ \\
Paraíba & $+0,127$ & $+0,187$ \\
Pernambuco & $-0,323$ & $-0,066$ \\
Ceará & $-0,199$ & $+0,010$ \\
Piauí & $-0,370$ & $-0,005$ \\
Rio Grande do Norte & $-0,574$ & $-0,027$ \\
Maranhão & $+0,077$ & $+0,182$ \\
Pará & $-0,410$ & $-0,217$ \\
Tocantins & 0,000 & $+0,117$ \\
Amazonas & $+0,221$ & $+0,119$ \\
Acre & $-0,639$ & $-0,452$ \\
Roraima & $+0,071$ & $+0,393$ \\
Rondônia & $-0,400$ & $+0,026$ \\
Amapá & $-0,385$ & $+0,104$ \\
\hline Total & $\mathbf{- 0 , 0 5 2}$ \\
\hline
\end{tabular}

Fonte: Os autores, a partir dos resultados eleitorais de 2000 e 2004 fornecidos pelo TSE.

a 500.000 eleitores), em comparação com as metrópoles. Neles, a disputa política já se encontra ideologizada, havendo dificuldade para a militância aceitar alianças muito heterogêneas, ao passo que a importância do cargo não é grande o suficiente para fazer com que incidam as 
pressões da direção partidária por uma composição com maior viabilidade eleitoral ${ }^{12}$.

Tabela 10

Índice de Viés Ideológico das Coligações do PT nas

Eleições de 2000 e 2004, por Porte do Município

\begin{tabular}{l|c|c}
\hline Eleitorado & $\mathbf{2 0 0 0}$ & $\mathbf{2 0 0 4}$ \\
\hline Menos de 5.000 & $+0,029$ & $+0,145$ \\
5.000 a 10.000 & $-0,073$ & $+0,087$ \\
10.001 a 50.000 & $-0,192$ & $+0,002$ \\
50.001 a 100.000 & $-0,378$ & $-0,124$ \\
100.001 a 500.000 & $-0,508$ & $-0,074$ \\
Mais de 500.000 & $-0,787$ & $-0,026$ \\
\hline Total & $\mathbf{- 0 , 1 6 5}$ & $\mathbf{+ 0 , 0 5 2}$ \\
\hline
\end{tabular}

Fonte: Os autores, a partir dos resultados eleitorais de 2000 e 2004 fornecidos pelo TSE.

Um dado adicional é obtido quando se computa um índice apenas para cabeças-de-chapa, isto é, candidatos a prefeito de outros partidos, apoiados pelo PT. No cômputo geral, a diferença é irrisória, mas nos municípios maiores o deslocamento à esquerda é bastante significativo. A quantidade de casos diminui muito, já que foi grande a tendência dos petistas de apresentarem candidatos próprios nas maiores cidades; ainda assim, os dados revelam a maior dificuldade de nelas apoiar candidatos de direita (Tabela 11).

Tabela 11

Índice de Viés Ideológico das Cabeças-de-Chapa Apoiadas pelo PT em 2004, por Porte do Município

\begin{tabular}{l|c|c}
\hline Eleitorado & Índice de Cabeça-de-Chapa & Cabeça-de-Chapa Petista \\
\hline Menos de 5.000 & $+0,127$ & $33,5 \%$ \\
5.000 a 10.000 & $+0,085$ & $37,8 \%$ \\
10.001 a 50.000 & $-0,035$ & $44,6 \%$ \\
50.001 a 100.000 & $-0,215$ & $64,7 \%$ \\
100.001 a 500.000 & $-0,393$ & $78,6 \%$ \\
Mais de 500.000 & $-0,333$ & $83,3 \%$ \\
\hline Total & $+\mathbf{0 , 0 4 8}$ & $\mathbf{4 1 , 2} \%$ \\
\hline
\end{tabular}

Fonte: Os autores, a partir dos resultados eleitorais de 2004 fornecidos pelo TSE. 
O índice de governo agrega informações relevantes. Para as eleições de 2004, atribuiu-se o valor +1 para os partidos que, ao lado do PT, compõem a base de sustentação do governo federal, identificados como PC do B, PL, PMDB, PMN, PP, PPS, PSB, PSL, PTB e PV, e o valor -1 para os partidos de oposição ao governo federal (PCO, PSTU, PDT, PFL, Prona e PSDB). Valeu, novamente, a posição oficial de cada diretório nacional à época das eleições. Os demais partidos, todos pequenos, sem relevância na política nacional, apresentam posição neutra ou ambígua em relação ao governo Lula e foram excluídos da base de cálculo ${ }^{13}$. O "índice de governismo das coligações" mostra uma nítida predominância de alianças com partidos pertencentes à base do governo, em todos os estados (Tabela 12).

O viés à esquerda e o viés governista nas coligações apresentam, como esperado, correlação negativa, calculada em - 0,48 . No entanto, o peso dos fatores locais parece predominante. $\mathrm{O}$ mais alto índice de governismo $(+0,877)$ é registrado no Acre, estado com o viés à esquerda mais pronunciado (-0,452). Mas é no Rio Grande do Sul, estado com o terceiro maior viés à esquerda $(-0,158)$, que se registra o pior índice de governismo $(+0,379)$. No Acre, sob o segundo governo estadual petista, foram reforçadas as parcerias com PC do B e PSB, legendas de esquerda na base do governo Lula, que também participam da administração petista local. No Rio Grande do Sul, por sua vez, o aliado preferencial foi o PDT, partido de esquerda com forte penetração regional, mas que havia rompido com a administração federal.

A Tabela 13 transfere o foco para o porte dos municípios. Naqueles com mais de 500 mil eleitores, nas eleições de 2004, é quase total a vinculação das coligações petistas com a base de apoio do governo federal. Em apenas um caso, uma legenda de oposição aparece coligada (o Prona, que, ao lado do PT, apoiou o candidato do PSB à prefeitura de Duque de Caxias, município do interior do Estado do Rio de Janeiro). Mesmo em municípios médios, a partir de 50 mil eleitores, a predominância de coligações com outras legendas governistas é significativa.

O contraste com as eleições de 2000 é instrutivo. Nas três faixas de municípios com maior eleitorado, os índices de governismo das coligações de 2004 praticamente espelham os de 2000 - isto é, o PT alia-se a apoiadores do governo Lula tanto quanto se aliava a opositores do governo Fernando Henrique Cardoso. 
Um Equilíbrio Delicado: A Dinâmica das Coligações do PT...

Tabela 12

Índice de Governismo das Coligações do PT em 2004, por Estado

\begin{tabular}{|c|c|}
\hline Estado & Índice \\
\hline Rio Grande do Sul & $+0,379$ \\
\hline Santa Catarina & $+0,529$ \\
\hline Paraná & $+0,469$ \\
\hline São Paulo & $+0,595$ \\
\hline Rio de Janeiro & $+0,531$ \\
\hline Minas Gerais & $+0,423$ \\
\hline Espírito Santo & $+0,485$ \\
\hline Mato Grosso do Sul & $+0,452$ \\
\hline Mato Grosso & $+0,503$ \\
\hline Goiás & $+0,501$ \\
\hline Bahia & $+0,586$ \\
\hline Sergipe & $+0,633$ \\
\hline Alagoas & $+0,626$ \\
\hline Paraíba & $+0,380$ \\
\hline Pernambuco & $+0,637$ \\
\hline Ceará & $+0,609$ \\
\hline Piauí & $+0,492$ \\
\hline Rio Grande do Norte & $+0,599$ \\
\hline Maranhão & $+0,422$ \\
\hline Pará & $+0,715$ \\
\hline Tocantins & $+0,564$ \\
\hline Amazonas & $+0,524$ \\
\hline Acre & $+0,877$ \\
\hline Roraima & $+0,625$ \\
\hline Rondônia & $+0,409$ \\
\hline Amapá & $+0,609$ \\
\hline Total & $+0,513$ \\
\hline
\end{tabular}

Fonte: Os autores, a partir dos resultados eleitorais de 2004 fornecidos pelo TSE.

O Gráfico 2 ilustra as estratégias eleitorais do PT em 2004, nos diferentes estados, mostrando o cruzamento entre o índice de viés ideológico (eixo X) e o índice de governismo (eixo Y) das coligações. Aparecem destacados Acre, Pará e Rio Grande do Sul, estados em que a predominância de coligações com as siglas mais à esquerda é mais acentuada 
Tabela 13

Índice de Governismo das Coligações do PT, nas Eleições de 2000 e 2004,

por Porte do Município

\begin{tabular}{l|c|c}
\hline Eleitorado & $\mathbf{2 0 0 0}$ & $\mathbf{2 0 0 4}$ \\
\hline Menos de 5.000 & $+0,177$ & $+0,421$ \\
5.000 a 10.000 & $-0,047$ & $+0,483$ \\
10.001 a 50.000 & $-0,312$ & $+0,563$ \\
50.001 a 100.000 & $-0,675$ & $+0,679$ \\
100.001 a 500.000 & $-0,798$ & $+0,714$ \\
Mais de 500.000 & -1 & $+0,961$ \\
\hline Total & $-\mathbf{0 , 2 2 0}$ & $+\mathbf{0 , 5 1 3}$ \\
\hline
\end{tabular}

Fonte: Os autores, a partir dos resultados eleitorais de 2000 e 2004 fornecidos pelo TSE.

\section{Gráfico 2}

Índice de Viés Ideológico e Índice de Governismo das Coligações do PT nas Eleições Municipais de 2004, por Estados

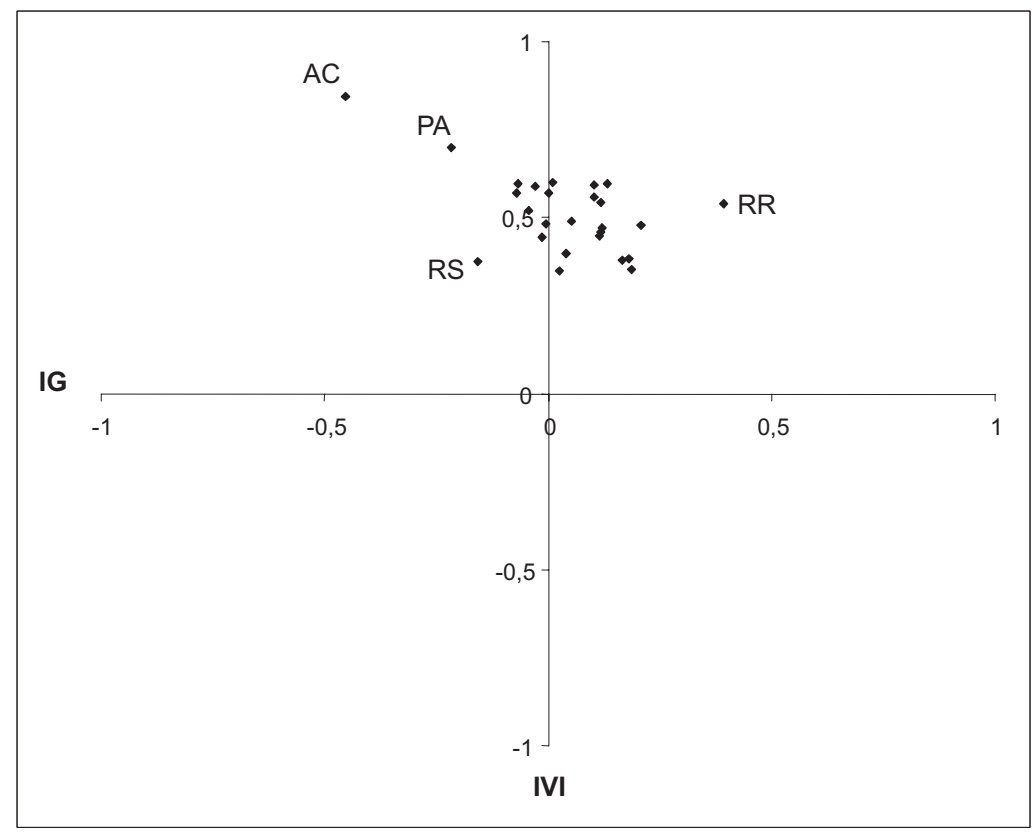

Fonte: Os autores, a partir dos resultados eleitorais de 2004 fornecidos pelo TSE. 
(como, no caso do Acre, um índice de governismo notavelmente mais elevado); e, no lado inverso, Roraima. Os 22 estados restantes formam um bloco compacto, próximo ao centro do eixo ideológico e com índice médio-alto de governismo.

\section{CONCLUSÕES}

Os quatro anos que separam 2000 de 2004 são apenas uma parcela na trajetória do Partido dos Trabalhadores. Um período importante, é claro, marcado pela vitória nas eleições presidenciais de 2002 que, por sua vez, emblematiza a guinada pragmática do partido em sua política de alianças (e, na verdade, em toda sua perspectiva diante do processo eleitoral). De acordo com Meneguello (1989), o momento da inflexão foi 1985, na escolha dos prefeitos das capitais e dos antigos municípios de segurança nacional. A partir daí, o PT teria começado a rever o impacto de seus compromissos ideológicos sobre sua estratégia eleitoral.

Há, contudo, um marco, posterior, que é mais significativo. Em 1989, ao chegar com Lula ao segundo turno das eleições presidenciais, o PT sentiu, pela primeira vez, que poderia alcançar o poder, pelo voto, em curto espaço de tempo. A partir daí, a obtenção de sucesso na competição eleitoral tornar-se-ia o objetivo cada vez mais exclusivo do partido. A postura leninista inicial, que via nas eleições um momento de educação política e entendia o partido como um instrumento de intervenção permanente na vida social, aos poucos sai de cena, e o PT se torna, plenamente, um partido eleitoral.

Mas esta conversão carrega as marcas da trajetória anterior do partido e da posição que ocupava no campo político brasileiro. No seu estudo já clássico sobre a social-democracia européia, Przeworski (1985) observa como a dinâmica da competição eleitoral levou os partidos operários à diluição de sua base social e à abertura para um discurso mais universalista. No caso do Partido dos Trabalhadores brasileiro, o projeto inicial de ser o representante político da classe operária foi combinado com um apelo mais amplo - o do partido diferente dos outros, fiel a seus princípios, afastado das barganhas escusas, transparente diante de seus militantes e do público. Enquanto o país vivia de escândalo em escândalo, os petistas permaneceram relativamente incólumes e fizeram do diferencial ético o instrumento para a superação do discurso classista inicial. 
Convém lembrar que, nas democracias contemporâneas, entre elas a brasileira, os partidos desfrutam do monopólio legal da representação política formal. Isto é, ainda que o sistema partidário possua baixa credibilidade, que a confiança popular nos partidos seja minguada, apenas eles podem disputar os cargos de poder. Mas, como estes estão em concorrência entre si, um diferencial de credibilidade representa um ativo valioso. Cada vez que este capital é utilizado - para avalizar uma aliança duvidosa, por exemplo - ele se desgasta. Trata-se, assim, de algo a ser utilizado com parcimônia, em momentos cruciais.

Entre 2000 e 2004, as coligações petistas ficaram ligeiramente maiores (de 2,8 para 2,9 partidos coligados) e se deslocaram sensivelmente para a direita (o índice de viés ideológico passa de $-0,165$ para $+0,052$ ). $O$ alinhamento no eixo governo-oposição, no entanto, se fortalece, com o índice passando de - 0,220 , um oposicionismo moderado ao governo Fernando Henrique Cardoso, para $+0,513$, uma forte prevalência de coligações com parceiros do governo Lula. Nas duas eleições, a variável mais importante é o porte do município. Quanto maiores, maior é a preocupação com a manutenção de algum tipo de coerência ideológica e maior é o peso do alinhamento na política nacional para a realização das coligações.

Os dados mostram que, quanto mais o PT se flexibilizou para constituir coligações das mais abrangentes possíveis, melhores foram os seus resultados. Ao mesmo tempo, a flexibilidade representa a redução do diferencial do partido. Contudo, não é possível desconsiderar o fato de que, mesmo o PT assimilando um comportamento eleitoral parecido com os partidos políticos tradicionais, ele ainda se apresenta como o único partido de grandes proporções a se diferenciar na forma como encara a disputa política. Sua taxa de coligação está entre as menores, caracterizando um comportamento desviante à regra para os partidos brasileiros.

As coligações do Partido dos Trabalhadores revelam a complexidade de sua estratégia. Ignorar por inteiro os incentivos que as regras eleitorais dão à formação de alianças significaria desperdiçar sistematicamente chances de vitória e, no limite, resignar-se a uma posição marginal permanente no campo político brasileiro, como parece ser o caso dos micropartidos trotskistas ${ }^{14}$. Mas aceitá-los sem ressalvas impediria a construção de um diferencial importante aos olhos de parcelas expressivas do eleitorado e de grupos da sociedade civil, transformando 
o PT em um partido igual aos outros - como aconteceu com o PPS, herdeiro do velho PCB.

Entre um extremo e outro, os petistas buscaram manter um equilíbrio delicado, ampliando sua força eleitoral, elegendo mais candidatos, mas mantendo sua identidade. O mosaico de coligações municipais mostra esta estratégia, em que a sensibilidade às questões locais e regionais - inevitável em um território tão vasto e diversificado quanto o Brasil - se combina com a manutenção de um perfil nacional coerente e distinto. A chegada ao poder federal, com as eleições de 2002, revelou um PT bem mais ajustado às práticas políticas tradicionais e bem mais à direita do que sua base eleitoral histórica desejava, mas ainda assim o partido se esforçou para (e, em alguma medida, logrou) manter-se como diferenciado. É o que revelam os discursos de campanha, como o do presidente Luiz Inácio Lula da Silva em 2006, e também o perfil de suas coligações.

A trajetória do PT é exemplar para o entendimento do funcionamento do campo político brasileiro. Ajustar-se às suas imposições foi essencial para o sucesso do partido, mas um ajuste demasiado perfeito o jogaria numa vala comum que o impediria de aproveitar diferenciais potencialmente valiosos. O resultado líquido, sob a perspectiva da busca da transformação social, foi a redução drástica da radicalidade do projeto petista. O que ilustra, mais uma vez de forma exemplar, o caráter tradicional das estruturas de nosso campo político.

(Recebido para publicação em janeiro de 2007)

(Versão definitiva em outubro de 2007) 


\section{NOTAS}

1. Dentre estes estudos é possível citar Azevedo (1995), Couto (1995; 1998), Keck (1991), Lacerda (2002), Meneguello (1989), Novaes (1993) e Oliveira (2003).

2. Faz-se aqui uma adaptação da idéia de "coalizão de amplitude [ideológica] mínima", apresentada por Lijphart (2003:119) em sua tipologia das coalizões parlamentares. Ao contrário do Parlamento, em que se conhece o peso de cada partido e, portanto, quão mínima pode ser a amplitude, na disputa eleitoral é impossível determinar em quantos votos cada apoio se traduz.

3. O que surpreende, no caso do PT, é o fato de ser o único partido constituído no período pós-ditatorial que foi produto de uma organização social e manteve laços estreitos com suas bases durante boa parte de sua existência.

4. As afirmações de Soares são refutadas por Oliveira (1973) e Santos (1987), enquanto são aceitas e retrabalhadas por Souza (1976), Sousa (1996), Lima Júnior (1983; 1993), Lavareda (1991), Fleischer (1984), Figueiredo (1994) e Schmitt (1999).

5. O estudo de Soares (1964) aborda a racionalidade do ponto de vista do partido. Contudo, ignora a constituição da intenção de voto pelo eleitor. Ao chamar de racional a ação partidária movida pelo fim de se eleger, retira-se da discussão a perspectiva do eleitor: como ele encara a organização partidária e percebe as opções a ele oferecidas no momento da eleição.

6. Não custa reforçar que, neste momento, o universo é dado pelas coligações, isto é, excluídos os municípios nos quais o partido disputou sozinho.

7. Os números do outro partido trotskista, o PCO, chamam a atenção - ele teria se coligado apenas em três ocasiões, mas a média chegaria a 6,3 partidos por coligação. É possível que exista um erro na base de dados do Tribunal Superior Eleitoral - TSE, sobretudo porque as coligações, sempre em pequenos municípios do interior, envolvem legendas de direita, incompatíveis com o perfil ideológico do PCO.

8. O índice foi desenvolvido em trabalho anterior (Miguel, 2004b).

9. Caso fossem incluídos, com valor 0 , a diferença nos resultados em geral se situaria na segunda casa decimal.

10. A maior parte das vitórias sem coligações, para qualquer dos partidos, ocorre nos municípios de pequeno porte, com menos de 5 mil eleitores. Em relação aos outros, porém, o PT apresenta uma proporção maior de vitórias em municípios um pouco maiores, com 10 mil a 50 mil eleitores.

11. Dado o perfil ideológico do PCO, a média de coligações parece alta, assim como chamam a atenção algumas de suas alianças, em municípios pequenos, com partidos à direita no espectro político. Não deve ser descartada, também para 2004, a possibilidade de erro nos dados do TSE.

12. As coligações vitoriosas integradas pelo PT têm viés ligeiramente mais à direita do que as derrotadas $(+0,093$ e $+0,012$, respectivamente). A regra vale para qualquer porte de município.

13. Caso fossem incluídos, com valor 0 , a diferença nos resultados em geral se situaria na segunda casa decimal.

14. Mas esta marginalização não é sentida como especialmente danosa para partidos com estratégia preferencial extra-eleitoral, como é o caso de PSTU e PCO. 


\section{REFERÊNCIAS BIBLIOGRÁFICAS}

AZEVEDO, Clovis Bueno de. (1995), A Estrela Partida ao Meio: Ambigüidades do Pensamento Petista. São Paulo, Entrelinhas.

BOURDIEU, Pierre. (1979), La Distinction: Critique Sociale du Jugement. Paris, Minuit. . (1989), “A Representação Política. Elementos para uma Teoria do Campo Político", in O Poder Simbólico. Lisboa, Difel.

COUTO, Cláudio Gonçalves. (1995), O Desafio de Ser Governo: O PT na Prefeitura de São Paulo (1989-1992). Rio de Janeiro, Paz e Terra.

. (1998), “A Longa Constituinte: Reforma do Estado e Fluidez Institucional no Brasil". DADOS, vol. 41, no 1, pp. 51-86.

FAVETTI, Paola Ramos. (2004), Partidos Aliados em Eleições Presidenciais no Brasil: Análise das Coligações Vencedoras em 1994, 1998 e 2002. Dissertação de mestrado em Ciência Política, UnB, Brasília.

FIGUEIREDO, Argelina. (1994), “O Desafio do Congresso Nacional: Mudanças Internas e Consolidação Institucional”. Cadernos de Pesquisa, vol. 3, pp. 1-59.

FLEISCHER, David. (1984), Do antigo ao Novo: Partidos e Sistemas Partidários no Congresso Nacional (1945-1984). Brasília, Câmara dos Deputados.

KECK, Margareth. (1991), PT, a Lógica da Diferença: O Partido dos Trabalhadores na Construção da Democracia Brasileira. São Paulo, Ática.

KRAUSE, Silvana. (2005), “Uma Análise Comparativa das Estratégias Eleitorais nas Eleições Majoritárias (1994-1998-2002): Coligações Eleitorais X Nacionalização dos Partidos e do Sistema Partidário Brasileiro", in S. Krause e R. Schmitt (orgs.), Partidos e Coligações Eleitorais no Brasil. Rio de Janeiro/São Paulo, Fundação Konrad Adenauer/Editora da Unesp.

LACERDA, Alan Daniel Freire de. (2002), “O PT e a Unidade Partidária como Problema". DADOS, vol. 45, no 1, pp. 39-76.

LAVAREDA, Antônio. (1991), A Democracia nas Urnas: O Processo Partidário Eleitoral Brasileiro. Rio de Janeiro, Rio Fundo/Iuperj.

LIJPHART, Arend. (2003) [1999], Modelos de Democracia: Desempenho e Padrões de Governo em 36 Países. Rio de Janeiro, Civilização Brasileira.

LIMA JÚNIOR, Olavo Brasil de. (1983), Os Partidos Políticos Brasileiros: A Experiência Federal e Regional (1945-1964). Rio de Janeiro, Graal.

. (1993), Democracia e Instituições Políticas no Brasil nos Anos 80. São Paulo, Loyola.

MAINWARING, Scott. (2001), Sistemas Partidários em Novas Democracias: O Caso do Brasil. Rio de Janeiro/Porto Alegre, FGV Editora/Mercado Aberto.

MENEGUELLO, Rachel. (1989), PT: A Formação de um Partido, 1979-1982. Rio de Janeiro, Paz e Terra.

MIGUEL, Luis Felipe. (2004a), “Discursos Cruzados: Telenoticiários, HPEG e a Construção da Agenda Eleitoral". Sociologias, no 11, pp. 238-258. 
. (2004b), Participação Eleitoral e Gênero no Brasil: As Cotas para Mulheres e seu Impacto. Trabalho apresentado no II Congresso da Associação Latino-Americana de Ciência Política - Alacip. Cidade do México, 29 de setembro a 2 de outubro.

. (2006), “A Palavra 'Aperfeiçoada': O Discurso do Partido dos Trabalhadores nas Eleições de 2002", in A. Lemos, C. Berger e M. Barbosa (orgs.), Narrativas Midiáticas Contemporâneas. Porto Alegre, Sulina.

NICOLAU, Jairo Marconi. (1996), Multipartidarismo e Democracia: Um Estudo sobre o Sistema Partidário Brasileiro (1985-1994). Rio de Janeiro, FGV Editora.

e PEIXOTO, Vitor. (2007), “As Bases Municipais da Votação de Lula em 2006". Cadernos do Fórum Nacional, Instituto de Altos Estudos. Disponível em http:// jaironicolau.iuperj.br/artigos\%20_files/FORUM-2007.pdf, acessado em julho de 2007.

NOVAES, Carlos Alberto Marques. (1993), "PT: Dilemas da Burocratização”. Novos Estudos Cebrap, no 35, pp. 217-237.

OLIVEIRA, Francisco de. (2003), “O Ornitorrinco", in Crítica à Razão Dualista - O Ornitorrinco. São Paulo, Boitempo.

OLIVEIRA, Isabel Ribeiro de. (1973), “Notas sobre o Comportamento das Coligações Eleitorais no Brasil (1950-1962)". DADOS, no 10, pp. 166-183.

OSAKABE, Haquira. (1987), “A Palavra Imperfeita”. Remate de Males, no 7, pp. 167-171.

PRZEWORSKI, Adam. (1985), Capitalismo e Social-Democracia. São Paulo, Companhia das Letras.

RIBEIRO, José Floriano. (2005), Acordos Partidários Nacionais, Reflexos Locais: O Presidencialismo de Coalizão enquanto Fator Estruturante das Alianças Eleitorais. Trabalho apresentado no XXIX Encontro Anual da Associação Nacional de Pós-Graduação e Pesquisa em Ciências Sociais - Anpocs. Caxambu, 25-29 de outubro.

RUBIM, Antonio Albino Canelas. (2003), Cultura e Política na Eleição de 2002: As Estratégias de Lula Presidente. Trabalho apresentado no XII Congresso da Associação Nacional dos Programas de Pós-Graduação em Comunicação - Compós. Recife, 2-6 de junho.

SANTOS, Wanderley Guilherme dos. (1987), Crise e Castigo: Partidos e Generais na Política Brasileira. São Paulo, Vértice.

SCHMITT, Rogério. (1999), Coligações Eleitorais e Sistema Partidário no Brasil. Tese de doutorado em Ciência Política, Iuperj, Rio de Janeiro.

. (2005), “Os Estudos sobre Alianças e Coligações Eleitorais na Ciência Política Brasileira”, in S. Krause e R. Schmitt (orgs.), Partidos e Coligações Eleitorais no Brasil. Rio de Janeiro/São Paulo, Fundação Konrad Adenauer/Fundação Editora da Unesp.

, CARNEIRO, Leandro Piquet e KUSCHNIR, Karina. (1999), “Estratégias de Campanha no Horário Gratuito de Propaganda Eleitoral em Eleições Proporcionais". DADOS, vol. 42, no 2, pp. 277-301.

SOARES, Gláucio Dillon. (1964), "Alianças e Coligações Eleitorais: Notas para uma Teoria". Revista Brasileira de Estudos Políticos, no 17, pp. 95-124.

(2001), A Democracia Interrompida. Rio de Janeiro, FGV Editora. 
SOUSA, Vivaldo de. (1996), As Coligações Partidárias no Período 1986-94 versus 1954-62. Dissertação de mestrado em Ciência Política, UnB. Brasília.

SOUZA, Maria do Carmo Campello de. (1976), Estado e Partidos Políticos no Brasil (1930 a 1940). São Paulo, Alfa-Ômega.

TAVARES, José Antonio Giusti. (1994), Sistemas Eleitorais nas Democracias Contemporâneas. Rio de Janeiro, Relume Dumará.

. (1998), Reforma Política e Retrocesso Democrático; Agenda para Reformas Pontuais no Sistema Eleitoral e Partidário Brasileiro. Porto Alegre, Mercado Aberto. 


\section{Lista de Siglas dos Partidos Políticos}

PAN - Partido dos Aposentados da Nação

PC do B - Partido Comunista do Brasil

PCB - Partido Comunista Brasileiro

PCO - Partido da Causa Operária

PDT - Partido Democrático Trabalhista

PFL - Partido da Frente Liberal

PGT - Partido Geral dos Trabalhadores

PHS - Partido Humanista da Solidariedade

PL - Partido Liberal

PMDB - Partido do Movimento Democrático Brasileiro

PMN - Partido da Mobilização Nacional

PP - Partido Progressista

PPB - Partido Progressista Brasileiro

PPS - Partido Popular Socialista

PRB - Partido Republicano Brasileiro

PRN - Partido da Reconstrução Nacional

Prona - Partido de Reedificação da Ordem Nacional

PRP - Partido Republicano Progressista

PRTB - Partido Renovador Trabalhista Brasileiro

PSB - Partido Socialista Brasileiro

PSC - Partido Social Cristão

PSD - Partido Social Democrático

PSDB - Partido da Social Democracia Brasileira

PSDC - Partido Social Democrata Cristão

PSL - Partido Social Liberal

PSN - Partido Solidarista Nacional

PST - Partido Social Trabalhista

PSTU - Partido Socialista dos Trabalhadores Unificado

PT - Partido dos Trabalhadores

PTC - Partido Trabalhista Cristão

PT do B - Partido Trabalhista do Brasil

PTB - Partido Trabalhista Brasileiro

PTN - Partido Trabalhista Nacional

PV - Partido Verde 


\begin{abstract}
A Delicate Balance: The Dynamics of the Workers' Party Alliances in the Brazilian Municipal Elections (2000 and 2004)

The article analyzes the alliances established by the Workers' Party (PT) in the 2000 and 2004 elections in all Brazilian municipalities. Over the course of Brazil's current democratic experience, the PT has proven to be the country's most successful party in establishing a "party name". For important segments of the electorate, the PT acquired its identity based on its link to the Left and its rejection of corrupt methods in traditional Brazilian politics. Meanwhile, the Brazilian political system offers strong incentives for a strategy of broad and indiscriminate alliances. Through an analysis of alliances in the municipal elections, centered on government-opposition and Left-Right dichotomies, the article shows how the PT dealt with the opportunities created by (and constraints imposed by) its position in the political camp.
\end{abstract}

Key words: alliances; Workers' Party; Brazilian political camp

\title{
RÉSUMÉ \\ Un Équilibre Délicat: La Dynamique des Alliances du Parti des \\ Travailleurs lors des Élections Municipales (2000 et 2004)
}

Dans cet article, on examine le profil des alliances établies par le Parti des Travailleurs (PT) lors des élections de 2000 et 2004 dans toutes les municipalités brésiliennes. C'est le PT qui a le mieux réussi à former une image de parti dans l'expérience démocratique brésilienne actuelle. Il a raffermi, auprès d'importantes tranches d'électeurs, une identité basée sur son appartenance à la gauche et son refus des méthodes corrompues de la politique traditionnelle, malgré le fait que le système politique brésilien encourage fortement les alliances élargies et floues. En analysant les alliances aux élections municipales, depuis les axes gouvernement-opposition et droite-gauche, on voit comment le PT a fait front aux occasions proposées et aux contraintes dérivant de sa position dans le champ politique.

Mots-clé: alliances, Parti des Travailleurs; champ politique brésilien 